\title{
Recent decline of roach Rutilus rutilus stock in a large river ecosystem in relation with its population dynamics
}

\author{
William Otjacques ${ }^{1, *}$, Adrien Latli ${ }^{1}$, Benoît Bernard ${ }^{1}$, Michaël Ovidio², \\ Eric Depiereux ${ }^{1}$ and Patrick Kestemont ${ }^{1, *}$
}

With 3 figures and 6 tables

\begin{abstract}
Studies dealing with quantitative decline of freshwater fish species with long-time series data are rather scarce and primarily limited to migratory species. We present an original work integrating over two decades investigations on roach (Rutilus rutilus L.) stock, one of the dominant cyprinid fish species in the River Meuse (Belgium). This study aimed to quantify changes in the stock of roach after recent indicators (captures from sport fishermen) suggested a sharp decline. Three methods were used: capture-mark-recapture (CMR) estimation, catch per unit of effort by gillnetting (CPUE) and long-term monitoring of fish-passes. Population dynamics of roach was also investigated. CMR method demonstrated a decrease of $91 \%$ of the roach stock compared to earlier data (1993-2003), with current densities close to 300 roach ha ${ }^{-1}$. This was also confirmed by a decrease of $95 \%$ in CPUEs and a decrease between 93 and $98 \%$ in two fish-passes during the same period. On the other hand, growth and mortality did not indicate radical changes before and after the decline was found. As roach stock decline is generalizable to the whole Belgian's Meuse following estimations in two other sites, further investigations are needed to explain the reasons underlying this decline in order to take conservation measures. First, the uptake of primary production (i.e. phytoplankton) by invasive clams is supposed. And secondly, an increase in predation pressure by the Great Cormorant is effective as this avian predator was found in high densities from 2000 until 2006.
\end{abstract}

Key words: catch per unit of effort; fish pass; gillnet, large river; mark-recapture model; roach decline.

\section{Introduction}

Understanding changes affecting community structure and ecosystem functioning is one of the main challenges of modern ecology (Poff et al. 1997). Compilation of large datasets, involving time series observations, is extremely useful to relate observed changes to disturbances of an ecosystem (Daufresne et al. 2003).

Estimates of fish stocks dynamics are frequently used to evaluate ecological interactions in aquatic communities. These estimates are also important in fisheries management to control exploitation of a stock to avoid its collapse in a near future (Peltonen et al. 1999). Results of fish stock assessment should be of sufficient quality. In fisheries management, serious errors have been made following inaccuracy in stock assessment. The exactness of an estimate with a particular method is rarely known (Bailey 1984). Although contradictory estimates can be made by different assessment methods (Schnute \& Hilborn 1993), conclusions are more secure if different methods give coherent estimates (Foote \& Stefansson 1993). To highlight abundance and structure of a particular species population is a real challenge, mainly in large riv-

\footnotetext{
Authors' addresses:

${ }^{1}$ Research Unit in Environmental and Evolutionary Biology, University of Namur, 61 Rue de Bruxelles, 5000 Namur, Belgium

${ }^{2}$ Laboratory of Fish Demography and Hydroecology, University of Liège, 22 Quai E. Van Beneden, 4020 Liège, Belgium

*Corresponding authors; william.otjacques@unamur.be; patrick.kestemont@unamur.be
} 
ers. All sampling techniques are biased to some degree when estimates of abundance, richness or distribution are needed (Olin et al. 2009). Stock evaluations rely on active capture of fish such as electrofishing or passive capture of fish such as gillnetting (Murphy \& Willis 1996; Goffaux et al. 2005), but these methods have their own limits. Gillnetting is size selective (Hamley 1975), tends to underestimate young individuals of a given species or species being more sedentary $(\mathrm{Ru}-$ lifson 1991). Size selectivity can be reduced by using gillnets with different mesh sizes (Goffaux et al. 2005). Electrofishing is widely considered as efficient for describing population structure but is not appropriate for large and deep rivers (Pusey et al. 1998). Moreover electrofishing efficiency is influenced by physical and chemical parameters, swimming capacities of fish (Casselman et al. 1990) and response to electric field may vary between species and size class (Pusey et al. 1998). In large rivers, combination of these two techniques allows both sampling of the main channel and of the banks (Goffaux et al. 2005).

Mark-recapture method first developed by Petersen (1896) is an alternative to the removal method (Thompson et al. 1998) and the most used technique for stock estimates in inland water (Gatz \& Loar 1988; Donkers et al. 2011). The assumptions of this model are a closed population, random distribution and same catch probability between mark and unmarked individuals of the same species (White et al. 1982) and no mark loss. The mark-recapture model is generally used for abundance estimates in small (Gresswell et al. 1997) to large lakes (Donkers et al. 2011; Dahm et al. 1992). This model is more appropriate for low capture efficiency or low stock (Laurent \& Lamarque 1975). Since the pioneer work of Petersen, several models based on mark-recapture have been developed (Begon 1979).

Catches per unit of effort (CPUE), instead of giving estimate densities, offer a view on proportional changes which occurred in an exploited fish population. Comparison of CPUE information and stock density assessment is more useful if changes occur in fish population can be detected by both methods (Peltonen et al. 1999).

In addition, monitoring of fish passes enables data collection on population dynamics taking into account the migratory part of the fish populations. The most common monitoring method is to catch fish in a trap disposed within or at the outflows of the pass (Larinier 1998). When performed during consecutive years, monitoring of fish pass is an efficient tool to quantify changes in fish population in a river such as a decline of a particular species (Mallen-Cooper \& Brand 2007).

Roach Rutilus rutilus (L., 1758) is one of the most commonly and widely distributed fish in European rivers (Kottelat \& Freyhof 2007) but is also considered as a potential pest where it has been introduced and became the dominant species. In these environments, its high abundance creates concern for the other species present (Giannetto et al. 2014). Native in Belgium, roach stock in the River Meuse has been investigated by mark-recapture using the Jackson method in 1993, in order to evaluate the need of a fish restocking programme to support a roach population subject to capture by sport fishermen. Its density was estimated at 3695 roach ha $^{-1}$ (Didier \& Micha 1996). Based on this stock assessment, it was decided to stop the roach restocking programme in different reaches of the River Meuse. The study was repeated 7 years later from 2000 to 2002 and the density was estimated between 3035 and 3145 roach ha ${ }^{-1}$ indicating a stable roach population in the River Meuse despite the absence of restocking (Evrard \& Micha 2003). The restocking programme was definitively abandoned. However, since these studies, according to indirect indicators (captures from sport fishermen), roach stock was decreasing.

This study aimed to quantify roach stock using three different methods (estimation by mark-recapture, catch per unit effort and fish pass monitoring) over the last decade in the River Meuse (Belgium). Results between different sites and years are presented and compared with previous investigations in the same area. The assessment methods were also confronted to secure conclusion about the importance of the decline. Growth and mortality parameters were also investigated to check if changes in population abundance have impacted vital population parameters.

\section{Study area}

The River Meuse is $905 \mathrm{~km}$ long and its total catchment area is $34584 \mathrm{~km}^{2}$ (Descy et al. 2009). The river rises in Eastern France and flows throughout Belgium and The Netherlands before meeting the Lower Rhine and forming the Dutch delta. It debouches in the North Sea (Fig. 1) (Descy 1987). The average slope of the River Meuse is $0.23 \%$ o (Micha \& Pilette 1988). The River Meuse is a regulated river but management has been conducted with few considerations for aquatic fauna. As a result, plant and animal biodiversity has decreased (Descy et al. 2009). In Belgium, the river looks like a bream zone (deep water and slow current) according to Huet zonation (Huet 1949) as a consequence of heavily canalisation during the last 150 years. Naturally, the river in Belgium is a barbel zone characterised by a greater current and a lower depth (Micha \& Pilette 1988). Fif- 
Table 1. Annual means of debit, temperature, suspended matter, nitrates and orthophosphates at Tailfer during the studied period.

\begin{tabular}{lcccccc}
\hline Years & $\mathbf{1 9 9 3}$ & $\mathbf{2 0 0 0}$ & $\mathbf{2 0 0 1}$ & $\mathbf{2 0 0 2}$ & $\mathbf{2 0 1 0}$ & $\mathbf{2 0 1 1}$ \\
\hline Debit $\left(\mathrm{m}^{3} \mathrm{~s}^{-1}\right)$ & 171 & 239 & 224 & 143 & 167 & 146 \\
Temperature $\left({ }^{\circ} \mathrm{C}\right)$ & 11 & 12.8 & 12.9 & 14.5 & 13.1 & 13.8 \\
Suspended matter $\left(\mathrm{mg} \mathrm{l}^{-1}\right)$ & 18 & 25 & 20 & 27.2 & 12.2 & 12.8 \\
Nitrates $\left(\mathrm{mg} \mathrm{l}^{-1}\right)$ & 2.6 & 2.7 & 2.6 & 2.5 & 2.7 & 2.9 \\
Orthophosphates $\left(\mathrm{mg} \mathrm{l}^{-1}\right)$ & 0.06 & 0.05 & 0.04 & 0.03 & 0.05 & 0.05 \\
\hline
\end{tabular}

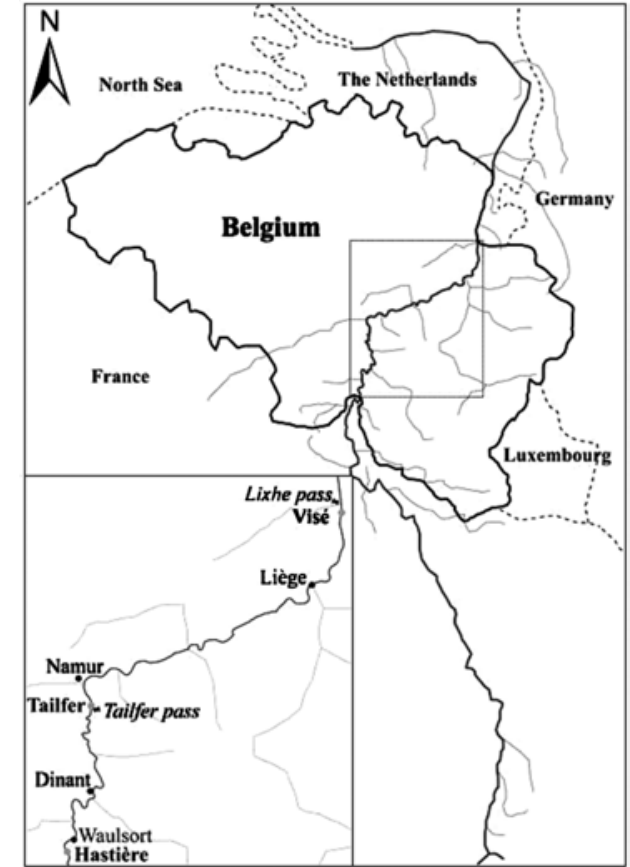

Fig. 1. Location of the River Meuse basin with the three sampling sites (bold names) and the two fish passes monitored.

teen dams have been built on its course in Belgium which allow shipping of 1350 tons upstream Namur (Tans 2000) and 9000 tons downstream Namur but disturb flow rate, migration of fish species and natural zonation patterns (Micha \& Pilette 1988). Natural banks are relatively rare as a result of canalisation. Over the past three decades, water temperature has increased by $0.16-0.89^{\circ} \mathrm{C}$ and discharge tends to increase. Eutrophication is widespread with organic pollution high in some parts of the river (Descy et al. 2009). In addition, invasive species, mostly macroinvertebrates, are present and widespread (Descy et al. 2009). During the study period at Tailfer (Belgium, $518 \mathrm{~km}$ from source), chlorophyll- $a$ and zooplankton have decreased drastically, presumably in response to invasive molluscs spread (Corbicula, Dreissena polymorpha, Dreissena rostriformis) (Pigneur et al. 2014). Extinction coefficient, inversely related to phytoplankton biomass, has increased. Soluble reactive phosphate presents a slight decrease. Nitrate and ammonium, temperature and discharge remain in the same range (Table 1) (Pigneur et al. 2014). In the Belgian's section of the River Meuse, 29 fish species were found during sampling by gillnetting and electrofishing from 1996 to 2012 (Table 2) with roach being the most abundant (Goffaux et al. 2005).
Table 2. Species list found in the River Meuse during sampling

\begin{tabular}{ll}
\hline Species & English name \\
\hline Abramis brama & Bream \\
Alburnus alburnus & Bleak \\
Alburnus bipunctatus & Stream bleak \\
Anguilla anguilla & Eel \\
Aspius aspius & Asp \\
Barbatula barbatula & Stone loach \\
Barbus barbus & Barbel \\
Blicca bjoerkna & Silver bream \\
Carassius carassius & Crucian carp \\
Chondrostoma nasus & Nase \\
Cottus gobio & Bullhead \\
Cyprinus carpio & Carp \\
Esox lucius & Pike \\
Gasterosteus aculeatus & Three-spined stickleback \\
Gobio gobio & Gudgeon \\
Gymnocephalus cernuus & Ruffe \\
Lepomis gibbosus & Pumpkinseed \\
Leuciscus idus & Ide \\
Leuciscus leuciscus & Dace \\
Perca fluviatilis & Perch \\
Phoxinus phoxinus & Minnow \\
Rhodeux sericeus & Bitterling \\
Rutilus rutilus & Roach \\
Salmo trutta fario & Trout \\
Sander lucioperca & Pikeperch \\
Scardinius erythrophtalmus & Rudd \\
Silurus glanis & European catfish \\
Squalus cephalus & Chub \\
Tinca tinca & Tench \\
\hline & \\
&
\end{tabular}

The present study was carried on three reaches in Belgium: Hastière, Tailfer and Visé located 488, 518 and $611 \mathrm{~km}$ respectively from the source (Fig. 1). The reach of Tailfer was previously studied by Didier \& Micha (1996) and Evrard \& Micha (2003).

\section{Material and methods}

\section{Fish sampling}

Estimates of roach stocks in the three sites have been based on the protocol (see below) described in Didier \& Micha (1996) and applied in the study of Evrard \& Micha (2003). Before es- 
timations, roach grown in captivity (Total length: 101-190 mm) in a fish farm were marked by clipping off the half right pelvic fin and restocked homogeneously immediately after marking.

The option to mark roach grown in fish farm for the markrecapture operations is due to several reasons: i) there were no other possibilities to catch and mark a large number of fish in a short period of time (one day); ii) the most efficient technique of roach capture in large rivers is gillnet, but this method is invasive and largely affects the survival rate of captured fish (Didier \& Micha 1996).

For restocking, marked roach stock were divided in several small tanks (500-1000 roach) placed at $200-300 \mathrm{~m}$ intervals along the banks. In the reach of Tailfer, 10,100 marked roach were stocked in 2010 and 10,000 in 2011. In the reaches of Hastière and Visé, 7,500 and 8,500 marked roach were stocked in 2012. In the reach of Tailfer, restocking was done at the end of March and sampling was conducted between April and Mai. In 2012, restocking and sampling were done in November.

To meet general assumptions of mark-recapture models, marking and recapture periods must be short (Krebs 1999 in Donkers et al. 2011). In the present study, samplings were completed within 4 days on each reach, less than a week after restocking of marked roach. This short period of time reduces the risk of method violations due to emigration and immigration. It's assumed that neither growth nor recruitment occurred during the sampling period (Ricker 1975). The closed population assumption appears to be met by dams delimiting each reach. Further, estimates have been conducted out of the reproductive period in order to avoid upstream migration of roach through fish passes. The assumptions of zero mark loss were addressed by fin clipping and correct reporting of mark by the use of three observers. Fin clipping was chosen for its facility and rapidity of marking and because of non-regeneration possible during the short period of sampling. Short period of time between marking and sampling should have reduced the probability of unequal mortality among unmarked and marked roach (Gresswell et al. 1997). Survival after marking was verified by maintaining in a tank placed in the River Meuse 30 marked and 30 unmarked roach for one month in 1993. No difference in survival rate was observed suggesting that marking didn't affect roach survival (Didier \& Micha 1996). We assumed an equal capture probability between marked and unmarked fish of the same size.

In 2010, 11 samples by gillnetting and 10 samples by electrofishing were done in the reach of Tailfer. In 2011, 12 samples by gillnetting and 8 by electrofishing were taken. In the reach of Hastière, 13 samples ( 5 by gillnetting and 5 by boat electrofishing) were collected in 2012. In the reach of Visé, 7 samples by gillnetting and only 3 by electrofishing were done because of low availability of bank less than $2 \mathrm{~m}$ deep.

Gillnetting was performed with a set of 3 to 6 gillnets (length: $50 \mathrm{~m}$; height: $2 \mathrm{~m}$ ) with different mesh sizes (20, 30 and $40 \mathrm{~mm}$ knot to knot). Gillnet $20 \mathrm{~mm}$ was preferred to other gillnets because its ability to catch fish of the size class restocked. Two to four gillnets were used per set. Gillnet $30 \mathrm{~mm}$ was used as an intermediate gillnet with one to two gillnets in the set. Gillnet $40 \mathrm{~mm}$ was used to a lesser extent (one gillnet per set). Samples were taken at different locations along reaches. Location selection was done randomly. Gillnets were exposed in the main channel for 2 to $6 \mathrm{~h}$ during daytime. This large difference is due to the high abundance of fish caught in gillnets. During the first $2 \mathrm{~h}$ of capture by gillnet, an electrofishing was carried out along shallow banks $(<2 \mathrm{~m})$ by boat (Zodiac $\AA$, $4.2 \mathrm{~m}$ long) in an upstream direction over a distance of $200-800 \mathrm{~m}$. All type of habitat found in the reaches were investigated proportionally to their abundance. The generator consists in a $3 \mathrm{KW}$ alternator delivering a continuous current ( $300 \mathrm{~V}$ at $4 \mathrm{~A}$, DEKA 7000). The cathode was floating on the rear side of the boat. Three persons were used, one boat driver, one dip netter and one handheld anode. After sampling, fishes were identified. Roach were measured to the nearest $\mathrm{mm}$ (Total Length, TL) and weighted to the nearest $\mathrm{g}$ individually. Identification as marked or unmarked roach was done by three persons for a correct reporting of marks.

\section{Stocks estimates}

Estimates have been investigated with the Jackson's positive method (1) (Jackson 1939). With this method, marking occurs on one occasion followed by multiple recaptures events (Begon 1979):

$$
N_{0}=\frac{r_{0}}{q_{0}}
$$

where

$N_{0}=$ total population estimated on day 0

$q_{0}=$ marked proportion of a hypothetical random sample taken on day 0

$r_{0}=$ number of individuals marked and released on day 0

Methods for estimating $q_{0}$ and confidence intervals of $N_{0}$ are from Begon (1979).

Estimations of $N_{0}$ were done with number of roach unmarked with size comprised between minimum and maximum size of roach marked. The total population was estimated by adding to $N_{0}$ a proportional estimate of roach outside of minimum and maximum size class defined by marked roach.

Estimate of total biomass $B(\mathrm{~kg})$ is calculated by the formula (2) using $N_{0}$ (1) and its confidence limits determined following method of Begon (1979):

$$
B=N * \bar{P}
$$

where $\bar{P}=$ Average weight $(\mathrm{kg})$

Estimates of density (roach ha $\left.{ }^{-1}\right)$ and biomass $\left(\mathrm{kg} \mathrm{ha}^{-1}\right)$ per hectare are calculated by dividing estimates of total population and its total biomass by the surface of each reach.

\section{Capture per unit of effort by gillnet}

In addition to stock estimates, stocks dynamics was also investigated with gillnet catches per unit of effort (CPUE) performed during stock evaluation. Even if CPUE is not an absolute estimate of density, it can show proportional changes in stocks (Peltonen et al. 1999). Data from gillnets with mesh size 20 and $30 \mathrm{~mm}$ were used following sufficient data. CPUEs are reported in number of fish caught per net per $30 \mathrm{~min}$ of fishing effort.

Because of unequal size samples and variance heterogeneity, we used Welch's Test F ratio (Welch 1951) to compare CPUEs. Multiple Welch paired-tests were performed to test significant differences between years in CPUEs with the same mesh size. Analysis of year samples will reinforce our confidence in changes revealed by mark-recapture estimates. Corrections for multiple paired-tests following the sequentially rejective multiple test procedure developed by Holm (1979). Comparisons with the same conclusion were grouped for facility and the $\mathrm{F}$ value, degrees of freedom and probabilities given referred to the highest statically $(p<0.05)$ significant difference observed. 


\section{Fish pass analysis}

In order to use different methods to reveal and quantify roach stock, two fish passes were monitored, at Tailfer dam on the Middle Meuse and at Lixhe dam on the Lower Meuse. At Tailfer pass, fish were captured by trap at the following years: 1989 to 1994,2006 and 2009 to 2011. This fish pass was monitored from March until December in 1989 to 1994 and from March until September in 2006 and 2009-2011. Fourteen pools composed the fish pass $(1.95 \times 1.50 \times 0.75 \mathrm{~m})$ each dropping in elevation by $0.13-0.15 \mathrm{~m}$. Discharge at the outlet is closed to $0.24 \mathrm{~m}^{3} \mathrm{~s}^{-1}$ and water velocity over the traverse is about $0.9 \mathrm{~m}$ $\mathrm{s}^{-1}$ (Prignon et al. 1998). The only trap was placed in the upper pool of the pass and had a cone at the entrance and a steel grid ( $1 \mathrm{~cm}$ wide between bars) at the exit. All fish were counted except young of the year and common bleak (Alburnus alburnus L.) because of high abundance during the nineties. During migration peaks (April-June), fish were collected daily. Outside migration period, the trap was checked twice a week.

Lixhe dam has two fish passes. The first was put into operation in 1980 and the second in 1998. Monitoring was done from January until June. The older is a pool and weir pass of $48 \mathrm{~m}$ length composed of 56 pools $(1.5 \times 0.9 \times 0.4 \mathrm{~m})$ with 2 cones trap at the upper pool. The new one is a pool and vertical slot pass of $305 \mathrm{~m}$ length composed of 26 pools $(1.4 \times 1.1 \times 1.5 \mathrm{~m})$ with a cage at the upper pool. The mean discharges were 0.135 and $1.0 \mathrm{~m}^{3} \mathrm{~s}^{-1}$ respectively. The older fish pass was monitored from 1992 to 2012, except years 1994 and 1996 and the new one from 1998 to 2012. Both old and new fish passes were monitored at least twice a week and all fish were counted except young of the year.

Roach abundance was expressed as catch in number per month. For each year, we divided fish abundance by the period of sampling (in month). At Tailfer pass, we compared the two periods of monitoring ranging from 1989 to 1994 (6 years) and from 2006 and 2009 to 2011 (4 years). As no great gap existed in the monitoring of the Lixhe pass, periods were determined to correspond closer to the periods of the Tailfer pass. More, data were ordered to check if chronology and decreasing were concordant. Periods compared were one before year 2000 (7 years), a second period from 2001-2006 (6 years) and a third period from 2007-2012 (6 years). Following high variance heterogeneity and unequal samples size, we used Welch's Test F ratio to compare CPUEs. Corrections for multiple paired-tests following the sequentially rejective multiple test procedure developed by Holm (1979).

\section{Dynamics of roach populations}

Age and growth rate were read from scales (Mann 1973). Between 3 and 10 scales were collected from 56 specimens caught in each reach. Scales were taken above the lateral line up the dorsal fin. After removing mucus, scales were placed between 2 microscope slides ( $(\mathrm{VWW})$. Annual radii were determined as the point where circuli became closely spaced followed by areas of widely spaced circuli. Annual radii were recorded only when structures could be viewed around the circumference of the scale (Cragg-Hine \& Jones 1969). Age reading was carried out independently by two persons. After age accordance, measures of radii (to the nearest $\mathrm{mm}$ ) were carried out on the posterior field using a binocular. Total length at different ages was back-calculated using the Lee (1920) formula based on measures of radii.

$$
L_{t}=a+\left(L_{n}-a\right) * \frac{R_{t}}{R_{n}}
$$

where

$L_{t}=$ back-calculated fish body length at age $t$

$a=$ intercept from the regression of body length on mean scale length

$L_{n}=$ fish body length at capture

$R_{t}=$ mean scale length at annulus $t$

$R_{n}=$ mean scale total length at capture

Growth was described by the Von Bertalanffy growth curve (VBGC) model (Von Bertalanffy 1938) described by the equation (4):

$$
L_{t}=L_{\infty} *\left(1-e^{-K *\left(t-t_{0}\right)}\right)
$$

where

$L_{t}=$ Total length at age $t$

$L_{\infty}=$ Asymptotic length or Maximal size

$K=$ Growth coefficient

$t_{0}=$ Hypothetical age when length equal 0

The method of Ford-Walford was used to determine asymptotic length $L_{\infty}$ which correspond to the intercept of the right $x=y$ and the regression of body length at time $t+1$ and body length at time $t$. Growth coefficient $K$ and theoretical age $t_{0}$ were determined using the Von Bertalanffy method (Sparre \& Venema 1996). We used Excel software to construct the VBGC model.

The index Ø' of growth performance (Pauly \& Munro 1984, Sparre \& Venema 1996, Naddafi et al. 2005) calculated by formula (5) was employed in order to compare growth between years and sites:

$$
\varnothing^{\prime}=\ln (K)+2 * \ln \left(L_{\infty}\right)
$$

The instantaneous rate of total mortality $Z$ was estimated using length-converted age catch curve using the equation of Von Bertalanffy and by reporting age on the X-axis and natural logarithm of number of individuals by cohort on the Y-axis. Cohorts under-estimated following a low sampling effort due to gears used were rejected for this analysis. The regression is equal to (6):

$$
\ln \left(N_{t}\right)=a+b * t
$$

Total mortality $Z$ is equal to - $b$ (Ricker 1975; Pauly 1997). Instantaneous rate of natural mortality $M$ was estimated using the empirical equation of Pauly (Pauly 1980) (7):

$$
\begin{aligned}
& \log (M)=-0,006-0,279 * \log \left(L_{\infty}\right)+ \\
& 0,6543 * \log (K)+0,4634 * \log (T)
\end{aligned}
$$

where $L_{\infty}$ and $K$ are from the $\operatorname{VBGC}(5)$

$T=$ Mean annual water temperature $\left({ }^{\circ} \mathrm{C}\right)$

Instantaneous rate of fishing mortality $F$ was calculated as the difference between instantaneous rates of total and natural mortality (8) (Sparre \& Venema 1996):

$$
F=Z-M
$$

The ratio of instantaneous rate of fishing and total mortality was calculated to estimate exploitation $E$ (9) (Sparre \& Venema 1996):

$$
E=F / M
$$




\section{Results}

\section{Density estimates}

In the reach of Tailfer, 761 unmarked roach were caught by electrofishing and gillnet in 2010 and 303 in 2011. In 2010, 222 marked roach were caught (Recapture rate of $2.2 \%$ ) and 104 in 2011 (Recapture rate of $1.04 \%$ ). Gillnet catches represented for this site $49 \%$ of the captures. A total of 462 unmarked roach were caught in the reach of Visé in 2012. Gillnet catches represented $99.8 \%$ of the captures. On 8500 marked roach, 71 have been recaptured during the sampling period. Recapture rate was $0.84 \%$. On the reach of Hastière, a total of 241 unmarked roach were caught, mostly by gillnet sampling (97\%). Recapture rate was $3.75 \%$ with a total of 281 marked roach caught. Most of the recaptures in this site were due to electrofishing (62\%) along the banks. Lengths of roach caught by electrofishing were relatively constant between 1993 and 2002. For years 2010-2012, size class length was reduced following low capture. Lengths of fish caught by gillnetting were constant along the two decades reflecting the selectivity of this method (Table 3 ).

Between 1993 and 2002, estimates by Jackson method reveal a steady stock of roach. According to this method, roach stock was estimated between 3695 [2554-5346] and 3035 [1950-4719] roach ha ${ }^{-1}$ (Table 4). Moreover, CPUEs obtained between 1993 and 2002 from gillnets with mesh size of 20 and $30 \mathrm{~mm}$ did not show any significant differences during that period (Fig. 2). In 2010 and 2011, roach stock has undergone a strong decrease in less than 10 years with estimated densities around 300 roach ha ${ }^{-1}$. Even if no historical data exists for the reaches of Hastière and Visé, roach stocks appeared close to the results obtained in the reach of Tailfer between 2010 and 2011. Density is estimated at 225 [205-248] roach ha ${ }^{-1}$ in Visé and 109 [60-197] roach ha ${ }^{-1}$ in Hastière.

\section{Gillnet surveys}

Total lengths of roach caught by $20 \mathrm{~mm}$ mesh size gillnets ranged between 101 and $250 \mathrm{~mm}$. For gillnet $30 \mathrm{~mm}$, total lengths of roach ranged between 121 and $340 \mathrm{~mm}$ (Table 2). Values and confidence intervals $(95 \%)$ of CPUEs are shown in Figure 2. CPUEs for 2010 were not used because fishing time was not reported. CPUEs obtained in 2011 and 2012 on both sites were not significantly different $\left(\mathrm{F}_{\text {Welch }}(1,19)=2.28\right.$; $p>0.147$ for gillnet of $20 \mathrm{~mm}$ and $\mathrm{F}_{\text {Welch }}(1,21)=63.47$; $p>0.625$ for gillnet $30 \mathrm{~mm}$ ). On the other hand CPUEs

Table 3. Date, site, area, recapture rate and minimum and maximum total length of roach restocked, caught by sampling methods and for stock estimations.

\begin{tabular}{llccrrrcc}
\hline Year & Site & Area (ha) & $\begin{array}{c}\text { Recapture } \\
\text { rate (\%) }\end{array}$ & Restocking & Electrofishing & $\begin{array}{c}\text { Gillnet } \\
\mathbf{2 0} \mathbf{~ m m}\end{array}$ & $\begin{array}{c}\text { Gillnet } \\
\mathbf{3 0} \text { mm }\end{array}$ & $\begin{array}{c}\text { Stock } \\
\text { estimations }\end{array}$ \\
\hline 1993 & Tailfer & 76.4 & 1.73 & $111-260$ & $51-270$ & $131-230$ & $171-310$ & $51-310$ \\
2000 & Tailfer & 76.4 & 2.16 & $81-190$ & $81-300$ & $141-250$ & $171-320$ & $81-370$ \\
2001 & Tailfer & 76.4 & 0.65 & $101-220$ & $71-360$ & $121-250$ & $121-310$ & $71-340$ \\
2002 & Tailfer & 76.4 & 1.31 & $91-250$ & $71-360$ & $121-250$ & $121-310$ & $71-370$ \\
2010 & Tailfer & 76.4 & 2.20 & $81-190$ & $151-160$ & $101-240$ & $121-340$ & $81-340$ \\
2011 & Tailfer & 76.4 & 1.04 & $111-240$ & $71-180$ & $101-240$ & $151-300$ & $71-320$ \\
2012 & Visé & 230.0 & 0.84 & $81-180$ & $141-150$ & $111-240$ & $191-300$ & $81-330$ \\
2012 & Hastière & 45.8 & 3.75 & $81-180$ & $61-160$ & $131-220$ & $201-280$ & $61-340$ \\
\hline
\end{tabular}

Table 4. Jackson estimates and resulted density and biomass obtained. Data from 1993 and 2000-2002 are reworked from Didier \& Micha (1996) and Evrard \& Micha (2003). $N_{0}$, roach stock estimation (roach comprised between minimum and maximum length of marked roach). Density and biomass include also estimation of roach outside length class defined by marked roach.

\begin{tabular}{|c|c|c|c|c|c|c|c|c|}
\hline \multirow[t]{2}{*}{ Year } & \multirow[t]{2}{*}{ Site } & \multirow[t]{2}{*}{$N_{0}$} & \multicolumn{3}{|c|}{ Density (roach ha ${ }^{-1}$ ) } & \multicolumn{3}{|c|}{ Biomass $\left(\mathrm{kg} \mathrm{ha}^{-1}\right)$} \\
\hline & & & Lower $95 \%$ & Mean & Upper $95 \%$ & Lower $95 \%$ & Mean & Upper $95 \%$ \\
\hline 1993 & Tailfer & 273445 & 2554 & 3695 & 5346 & 138.6 & 200.6 & 290.2 \\
\hline 2000 & Tailfer & 240248 & 2021 & 3145 & 4892 & 112.3 & 174.7 & 271.8 \\
\hline 2002 & Tailfer & 180025 & 1950 & 3035 & 4719 & 108.3 & 168.6 & 262.2 \\
\hline 2010 & Tailfer & 27885 & 380 & 473 & 590 & 16.8 & 20.9 & 26.0 \\
\hline 2011 & Tailfer & 10584 & 91 & 149 & 243 & 5.7 & 9.3 & 15.1 \\
\hline 2012 & Visé & 433752 & 205 & 225 & 248 & 10.3 & 11.3 & 12.5 \\
\hline 2012 & Hastière & 3609 & 60 & 109 & 197 & 2.9 & 5.3 & 9.5 \\
\hline
\end{tabular}




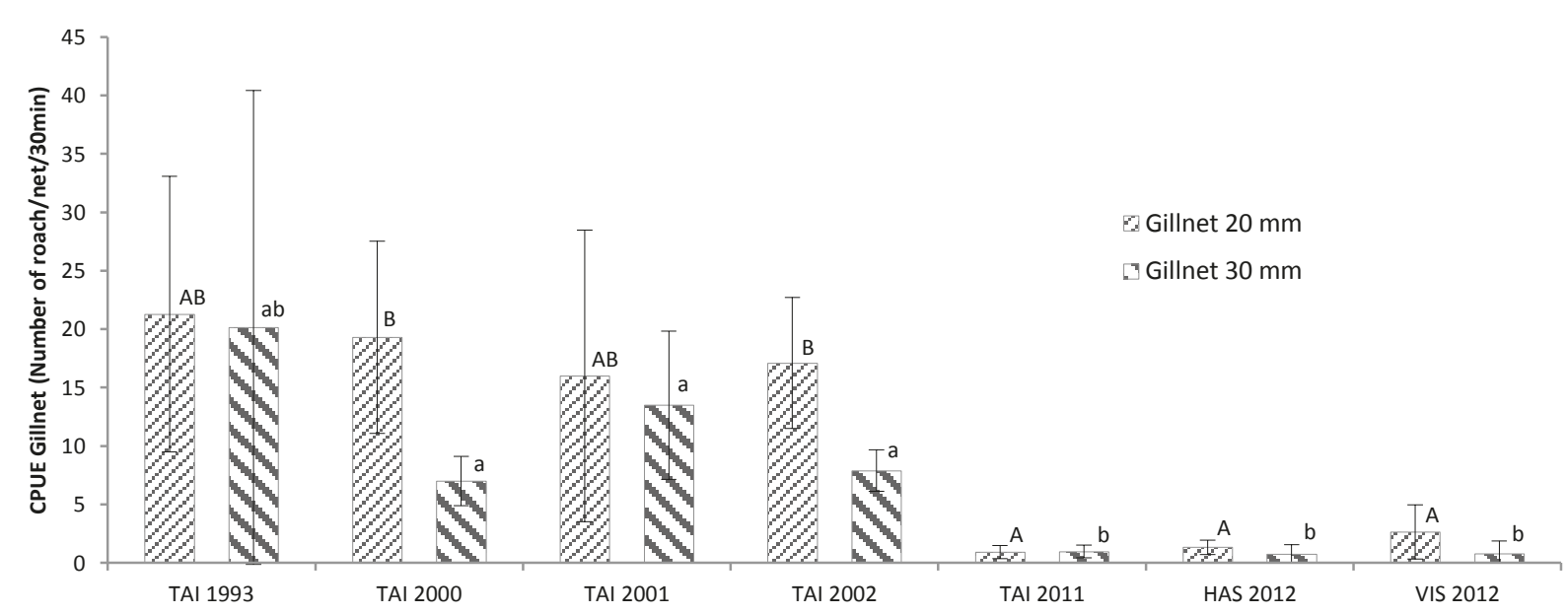

Fig. 2. CPUE for gillnet 20 and $30 \mathrm{~mm}$ obtained in the reaches of Tailfer (TAI), Hastière (HAS) and Visé (VIS), errors bars: $95 \%$ interval of confidence around estimated mean values based on specified number of observation per group represented by each bar. Items with the same letter (uppercase for gillnet with mesh size of $20 \mathrm{~mm}$, lowercase for $30 \mathrm{~mm}$ ) are not significantly different. Data from 1993 and 2000-2002 are reworked from Didier \& Micha (1996) and Evrard \& Micha (2003).

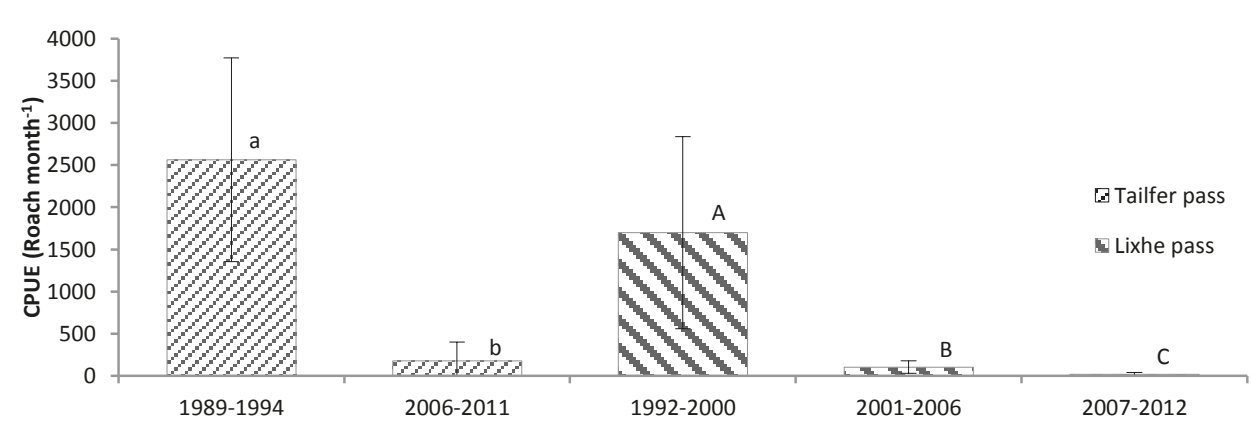

Fig. 3. Evolution of the catch per unit effort (Roach month ${ }^{-1}$ ) at the Tailfer and Lixhe passes, errors bars: $95 \%$ interval of confidence around estimated mean values based on specified number of observations (year) per group represented by each bar. Items with the same letter (lowercase for Tailfer, uppercase for Lixhe) are not significantly different

in 2011 and 2012 for gillnets with mesh size of $20 \mathrm{~mm}$ significantly lower from those calculated for 2000 and $2002\left(\mathrm{~F}_{\text {Welch }}(1,23)=16.56 ; p<0.008\right)$ but were not significantly lower for CPUEs from 1993 and 2001 $\left(\mathrm{F}_{\text {Welch }}(1,6)=17.72 ; p>0.084\right)$ after correction with sequentially rejective Bonferroni test and following the high variability for these years. CPUEs in 2011 and 2012 for gillnets of $30 \mathrm{~mm}$ were highly different from 2000, 2001 and $2002\left(\mathrm{~F}_{\text {Welch }}(1,15)=17,61 ; p<0.0008\right)$ but not significantly from $1993\left(\mathrm{~F}_{\text {Welch }}(1,6)=5,44\right.$; $p>0.06)$. CPUEs values for gillnets of $20 \mathrm{~mm}$ did not significantly differ between years 1993, 2000, 2001 and $2002\left(\mathrm{~F}_{\text {Welch }}(1,19)=0.48 ; p>0.494\right)$. Captures with gillnets of $30 \mathrm{~mm}$ were similar when comparing the years 1993, 2000, 2001 and $2002\left(\mathrm{~F}_{\text {Welch }}(1,18)=4.27\right.$; $p>0.05$ ) (Fig. 2).

\section{Fish pass analysis}

From 1989 to 1994, a mean of 2565 roach per month were captured at Tailfer pass. During last years (2006, 2009-2011), we noticed on average 179 roach per month (Fig. 3). Comparison of the two periods indicates a highly significant decrease in the number of roach passing through the pass $\left(\mathrm{F}_{\text {Welch }}(1,5)=25.20\right.$; $p=0.004)$. Between these periods, we noticed a decrease of $93 \%$ in roach passages. At Lixhe pass, during the first period (1992-2000), on average 1699 roach were counted per month, 103 during the second period (2001-2006) and only 19 during the third one (2007-2012) (Fig. 3). Comparison of the three periods reveals a significant decrease $\left(\mathrm{F}_{\text {Welch }}(1,6)=11.70\right.$; $p<0.014$ ) of $94 \%$ between the first two periods, $81 \%$ 
Table 5. Growth parameters of VBGC, performance index ( $\left.\varnothing^{\prime}\right)$, mortalities and exploitation of roach. $L_{\infty}$, asymptotic total length; $K$, growth rate; $t_{0}$, hypothetical age when length equals $0 ; Z$, total mortality; $M$, natural mortality; $F$, fishing mortality; $E$, exploitation. $R^{2}$ is the coefficient of determination of the regression of natural logarithm of number of individuals by cohorts on age.

\begin{tabular}{|c|c|c|c|c|c|c|c|c|c|c|}
\hline Sites & Year & $\boldsymbol{L}_{\infty}$ & K & $t_{0}$ & O' & $Z$ & M & $F$ & $E$ & $R^{2}(Z)$ \\
\hline Tailfer & 2010 & 302 & 0.20 & -1.0 & 9.8 & 0.92 & 0.45 & 0.47 & 0.51 & 0.94 \\
\hline Tailfer & 2011 & 316 & 0.18 & -0.6 & 9.8 & 0.60 & 0.40 & 0.20 & 0.33 & 0.96 \\
\hline Hastière & 2012 & 438 & 0.15 & -0.8 & 10.3 & 0.82 & 0.33 & 0.49 & 0.60 & 0.96 \\
\hline Visé & 2012 & 385 & 0.21 & -0.6 & 10.3 & 0.78 & 0.45 & 0.33 & 0.42 & 0.92 \\
\hline
\end{tabular}

between the last two periods and $98 \%$ between the first and last periods.

\section{Dynamics of roach populations}

Following low capture of young roach due to the gears (gillnet more precisely) used, dynamic analysis was performed with roach older than $1+$ until $8+$. Scales were taken on 56 fish taken during sampling taking account of length frequency. It appears that roach populations in the reaches of Hastière, Tailfer and Visé have a growth $K$ comprised between 0.15 and 0.21 year $^{-1}$. Asymptotic lengths $L_{\infty}$ estimated in 2012 are higher to those estimated at Tailfer in 2010 and 2011 (Table $5)$. For the reach of Tailfer, asymptotic length tends to decrease between estimates of 2010/11 and 1993/2002 while growth remains stable (Tables $5 \& 6$ ). Growth performance index $\varnothing^{\prime}$ reveals a low variability between estimates. The highest values are found in the reaches of Visé and Hastière (Table 5).

Exploitation, which reflects all types of mortalities, was high in the reach of Hastière. In the reach of Visé, exploitation was lower and comprised between estimates for the reach of Tailfer (Table 5).

\section{Discussion}

A strong decline in roach stock has been observed in the River Meuse in the past decade according to direct indicators such as stock estimates by mark-recapture, catch per unit effort with gillnet and roach passages at two fish passes. According to mark-recapture model, roach stock declined by $91 \%$ in the reach of Tailfer reaching densities of 300 fish ha ${ }^{-1}$. Size class investigated are of the same order. At the same time, a decrease of $95 \%$ in CPUE by gillnetting was observed. The study of Tailfer pass provided the same conclusion with a decrease of $93 \%$ in roach passages. Other stock estimates conducted in the reaches of Hastière and Visé showed that the decline observed at Tailfer can be extrapolated to the whole Belgian Meuse as stocks at Hastière and Visé reaches were low too. In addition, study of the Lixhe pass (adjacent to the reach of
Visé) has shown a similar decrease, higher than $96 \%$ of roach passages. Growth and mortality presented no radical changes suggesting that the decrease in density did not influence vital population parameters.

\section{Estimates of roach density}

Choice of mark-recapture method instead of removal method was due to high complexity for applying removal method in the River Meuse, which is a large $(>100 \mathrm{~m})$ and deep $(>2 \mathrm{~m})$ river. As Kelso and Shuter (1989) doubt on the efficiency of removal method for lake populations, same conclusions can be drawn for great rivers. For such environments, the mark-recapture is the most used method (Donkers et al. 2011; Gresswell et al. 1997). The principle of the Jackson method is that marking occurs on one occasion only and followed by several recaptures (Begon 1979). As mentioned before, all roach were marked on a single day. This single mass-marking was followed by multiple recapture events by a trained team. These two aspects make the use of the Jackson's positive method efficient and extremely useful. This method is an extension of the Petersen method which allows loss but no gain (Begon 1979).

The choice we made of fish grown in fish farm can have some biases due to the behaviour of these fish when released in the wild. For example, in the reach of Hastière, a lot of marked roach stayed hidden in aquatic vegetation more present in this reach (personal observation) which can lead to underestimate the natural population by increasing marked fish capture. Recapture rate in this reach was the highest in this study. Moreover, these fish can suffer higher mortality rate than wild fish of the same age (Brown \& Laland 2001; Phillipart 1995).

Although the analysis of fish pass data is an indirect and selective fish inventory method, inherently unique, it is an important tool in river management to control fish populations (Roscoe \& Hinch 2010). Furthermore, in great rivers, there are no methods which can offer a perfect sample fully representative of fish fauna. Electrofishing and gillnetting have also their 
own limits (Pusey et al. 1998; Casselman et al. 1990), as demonstrated by Goffaux et al. (2005).

Our results indicate that abundance of roach estimated by mark-recapture in the River Meuse in 2010-2012 was very low compared with earlier data (1993-2003) obtained with the same protocol. In the three monitoring sites, recent estimates were below 500 roach ha ${ }^{-1}(61-340 \mathrm{~mm})$. The lowest density was found in the reach of Hastière with 109 roach ha ${ }^{-1}$ (61-340 mm). According to previous estimates based on the Jackson method, a density relatively stable comprised between 3000 and 3700 roach ha $^{-1}(51-370 \mathrm{~mm})$ was found.

In the River Thames (England), roach stock has been investigated by mark-recapture by Williams (1965) and its density was estimated at 10000 roach $\mathrm{ha}^{-1}$ for fish over $10 \mathrm{~cm}$ fork length. In Lake Tjeukemeer (The Netherlands), roach density was estimated at 585 roach $\mathrm{ha}^{-1}$. This low density was attributed to scarcity of zoobenthos and competition from other species (Goldspink 1979). In Lake Årungen, a eutrophic lake in Norway, biomass of roach was estimated at $550 \mathrm{~kg} \mathrm{ha}^{-1}$ in the 1980s (Eie \& Borgstørm 1981). Eutrophication can have profound effects on fish communities, with cyprinid fishes such as roach dominating communities in these environments (Willemsen 1980, Winfield 1992). The River Meuse is a eutrophic river that corroborates well with the high density of roach found in the 1990s and beginning of 2000s. Recent studies reported that nutrient concentrations, which could explain such decline in fish stocks, didn't show any sharp decrease during the study period (Pigneur et al. 2014), suggesting that other causes such as bivalves or a high pressure predation should be responsible of such drastic decline in roach density.

Gillnet CPUE has been widely used as an important parameter in monitoring abundance changes or like an index of fish abundance (Olin et al. 2002; Olin et al. 2009; Mehner et al. 2005). Statistical comparisons of CPUEs corroborate the conclusion about the decrease in estimated densities. CPUEs obtained in 2011 and 2012 by gillnets are significantly lower than those obtained in previous studies except in 1993 (gillnets of 20 and $30 \mathrm{~mm}$ ) and 2001 (gillnets of $20 \mathrm{~mm}$ ). As roach stocks are low, CPUEs are low too.

We can assert that the use of fish pass data confirms what other methods revealed. Time-series study of fish pass indicated a decrease of $93 \%$ in roach passages, in accordance with the decrease of $95 \%$ revealed by CPUE with gillnet and with the decrease of $91 \%$ in roach stock estimates at Tailfer reach. Based on these observations and considering also the marked decline in roach passages in the Lixhe pass (reach of Visé), it appears that roach population in the Belgian section of the River Meuse decreased by almost $90 \%$ since the beginning of the 2000 s.

\section{Growth and mortality of roach}

Growth of roach can be considered as normal in the monitoring sites. The parameter $K$ is comprised between 0.15 and 0.21 year $^{-1}$, in line with past estimates in

Table 6. Values reported in literature of growth parameters of VBGC, performance index ( $\left.\varnothing^{\prime}\right)$, mortalities and exploitation of roach. $L_{\infty}$, asymptotic total length; $K$, growth rate; $t_{0}$, hypothetical age when length equals $0 ; Z$, total mortality; $M$, natural mortality; $F$, fishing mortality; $E$, exploitation. $R^{2}$ is the coefficient of determination of the regression of natural logarithm of number of individuals by cohorts on age.

\begin{tabular}{|c|c|c|c|c|c|c|c|c|c|c|}
\hline Sites & Reference & Year & $\boldsymbol{L}_{\infty}$ & $\boldsymbol{K}$ & $\theta^{\prime}$ & $Z$ & $M$ & $F$ & $E$ & $R^{2}(Z)$ \\
\hline Meuse at Waulsort & & 1989 & 421 & 0.15 & 10.2 & & & & & \\
\hline Meuse at Waulsort & & 1990 & 451 & 0.12 & 10.1 & & & & & \\
\hline Meuse at Tailfer & Evrard \& Micha 2003 & 2000 & 431 & 0.12 & 10.0 & & & & & \\
\hline Meuse at Tailfer & Evrard \& Micha 2003 & 2001 & 322 & 0.22 & 10.0 & & & & & \\
\hline Meuse at Tailfer & Evrard \& Micha 2003 & 2002 & 371 & 0.19 & 10.2 & & & & & \\
\hline Meuse at Tailfer & Evrard \& Micha 2003 & $2000-2002$ & 368 & 0.18 & 10.1 & 0.69 & 0.38 & 0.31 & 0.45 & 0.96 \\
\hline Lake Sapanca (Turkey) & Okgerman et al. 2009 & & $318-472$ & $0.11-0.19$ & $9.9-10.1$ & & & & & \\
\hline River Watra (Poland) & Przybylski 1996 & & & $0.13-0.27$ & & & & & & \\
\hline Lake Maggiore (Italy) & Volta \& Jepsen 2008 & & 357 & 0.29 & 10.5 & & & & & \\
\hline Lake Piediluco (Italy) & Giannetto et al. 2014 & & 478 & 0.24 & 10.9 & & & & & \\
\hline Lake Geneva (France) & Ponton \& Gerdeaux 1987 & & & 0.21 & 10.1 & & & & & \\
\hline England & Wyatt 1988 & & 425 & & & & & & & \\
\hline Netherlands & Goldspink 1979 & & 206 & & & & & & & \\
\hline
\end{tabular}


the reaches of Tailfer and Waulsort (Table 6). In other countries, growth rates range from 0.11 (Okgerman et al. 2009) to 0.30 (Guthruf 2002). Regarding asymptotic length, populations examined in the present study display maximal lengths of 438 and $385 \mathrm{~mm}$ which are close to the values previously reported in Tailfer and Waulsort. These values are greater than those reported in the literature (see Table 6). The $\varnothing^{\prime}$ values are 10.3 at Hastière and Visé, slightly greater than values reported in previous estimates in Tailfer and Waulsort. Current values at Tailfer are lower than the past ones. Values reported in literature are between 9.9 (Okgerman et al. 2009) and 10.9 (Giannetto et al. 2014). The obtained $\varnothing$ ' values of roach were very close to reported values from other countries. Regarding values reported in literature for roach growth rate, maximal length and the index of growth performance, values reported in this study are in line with the biology of this species. More, decline of roach population in the River Meuse had no detectable impact on vital parameter of this species.

Current estimates of total mortality ( 0.78 to 0.92 year $\left.^{-1}\right)$ are higher than past values $(0.69$ to 0.71 year $\left.^{-1}\right)$ except for the year $2011\left(0.60\right.$ year $\left.^{-1}\right)$. In terms of survival, current estimates are between 0.40 and 0.55 and past values are between 0.49 and 0.50 . Vøllestad \& L'Abée-Lund (1987) found that survival of mature male and female was 0.30 and 0.52 and did not vary with age. An et al. (2009) found for mature female and male values of survival of 0.53 and 0.50 , respectively.

Assumptions of the method used for estimating total mortality $Z$ are a constant mortality for all ages considered in the evaluation and a large sample covering a maximum number of cohorts. Each cohort must be recruited in equal quantities and, up to a critical length, vulnerability of each group to capture is supposed constant (Pauly 1997). First and second assumptions can be considered as respected. Populations of roach in the reaches studied exhibited relatively constant total mortality over the entire range of ages sampled which is reflected by a high coefficient of determination (Table 5). For the evaluation of $Z, 7$ to 8 cohorts were used. Third and fourth assumptions have been respected by rejecting from the analysis cohorts that were under-estimated following a low sampling effort due to gears used.

In an exploited stock, natural mortality is the most difficult parameter to estimate but is important for models of stock management. A priori, this mortality must be estimated in unexploited stocks (Pauly 1997). Due to the stock exploitation in the River Meuse and insufficient catch curve, we used the equation devel- oped by Pauly (1980) to estimate natural mortality. In the present study natural mortality was very close to previous estimates in the reach of Tailfer. Fishing mortality was high in roach stock of Hastière, leading to an over exploitation (60\%). In the reach of Visé, exploitation was similar to past estimates at Tailfer. In the reach of Tailfer, exploitation remained constant between 1993 and 2002. A slight increase is observed for the year 2010. In 2011, exploitation was low (33\%). The use of parameters in Pauly's equation has been revisited by Griffiths and Harrod (2007). The use of K, $L_{\infty}$ and $T$ for determining natural mortality is a good agreement but habitat and taxon are also important factors which have to be taken into account (Griffiths \& Harrod 2007). Estimating natural mortality can also be based on capture-recapture analyses of tagged individuals (Quinn \& Deriso 1999; Donkers et al. 2011) but this method is time consuming due to tagging of fish and recapture.

\section{Potential causes of decline}

Different reasons can be proposed to explain the observed drastic change of the most common fish in the River Meuse. Alteration of habitat heterogeneity for navigation has conducted to a decrease of biodiversity in the River Meuse (Descy et al. 2009). However, channelization, deepening of the river bed and stabilisation of banks were done in the last century (Micha \& Borlée 1989) and thus cannot be considered as the main causes of the recent decline observed for roach. But these perturbations can facilitate the establishment of invasive species potentially harmful for freshwater fauna.

Since several years, water quality of the River Meuse tended to improve following the construction of many sewage treatment plants (Descy et al. 2009). But nutrient levels (C, P and N) still remained rather stable during the last decade (Latli et al. unpublished). However, from the mid-2000s, an unexpected drastic decline in phytoplankton biomass has been reported while nutrients are still sufficient for plankton growth. As phytoplankton growth conditions have improved rather than degraded, Pigneur et al. (2014) hypothesized an increase of losses linked to the spectacular invasion of Asian clams, Corbicula sp. The decline in plankton biomass can lead to a "bottom-up" effect on fish populations following the $70 \%$ loss of primary production (Pigneur et al. 2014) which cannot be replaced by macrophytes because of river channelization. For example, in the San Francisco Bay, the invasion by the Asiatic clam Pomatocorbicula amurensis resulted in the decline of plankton (Alpine \& Cloern 
1992; Kimmerer et al. 1994) and, consequently, of plankton-feeding fish (Moyle et al. 1992). On the other hand, spread of invasive molluscs can increase the biomass of benthophagous fish, as shown by Karatayev et al. (1997) in Eastern Europe.

Population of Great Cormorant (Phalacrocorax carbo) has established a wintering population in the River Meuse valley since 1991 (Clotuche \& Schaeken 1991) and colonized reach of Tailfer in 1994. More generally, after a constant period of growth $(16 \%$ per year) until 2001, the Great Cormorant population along the Meuse River stood high until 2004. Since 2004, the wintering population declined progressively by $67 \%$ per year until 2009 while birds started colonizing more intensively small tributaries (Paquet 2007, 2011). Since 2010, the population along the River Meuse remained very low and stable. This observation can suggest a "top-down" effect of Great Cormorant on fish stock during its period of outbreak as roach is one of its favourite preys. In 2002, it was found that roach represent $33 \%$ of prey found in the diet of Great Cormorant in the reach of Tailfer (Evrard \& Tarbe 2002). Evrard et al. (2005) estimated a consumption of roach by cormorant between 21.9 and $24 \mathrm{~kg} \mathrm{ha}^{-1}$ year $^{-1}$.

These changes in predation pressure and primary production can be highlighted as potential causes of roach population decline and more investigations are needed in order to determine which ones are the most impacting on fish population and communities in the River Meuse to make conservation measures efficient.

\section{Acknowledgments}

We thank the field crew, especially André Evrard and Julien Lorquet, for their great expertise and support in fish samplings. We also thank the staff of the Fishery Service (General Directorate O3, Public Service of Wallonia) for its contribution to fish marking. Special thanks to Victor Paquay for the monitoring of the Tailfer pass and to Arnaud Dierckx and Gilles Rimbaud for the monitoring of the Lixhe pass. Special tanks to Jean-Yves Paquet for data of Great Cormorant. This work was supported by the Public Service of Wallonia and the European Fisheries Fund (contract FEP 32-1109-004).

\section{References}

Alpine, A .E. \& Cloern, J.E., 1992: Trophic interactions and direct physical effects control phytoplankton biomass and production in an estuary. - Limnology and Oceanography 37: 946-955.

An, W., Hu, J., Giesy, J.P. \& Yang, M., 2009: Extinction risk of exploited wild roach (Rutilus rutilus) populations due to chemical feminization. - Environmental Science \& Technology 43: 7895-7901.

Bailey, R. S., 1984: Comparison with other methods. - In: Craig, R. E. (ed.): Fisheries acoustics. - Rapp. P.-v. Réunion Cons. Int. Explor. Mer, vol 184, pp. 119-122.
Begon, M., 1979: Investigating animal abundance: capturerecapture for biologist. - Edward Arnold, United Kingdom, pp. 1-97.

Brown, C. \& Laland, K., 2001: Social learning and life skills training for hatchery reared fish. - Journal of Fish Biology 59: 471-493.

Casselman, J. M., Penczak, T., Carl, L., Mann, R. H. K., Holcik, J. \& Woitowich, W.A., 1990: An evaluation of fish sampling methodologies for large river systems. - Polish Archives of Hydrobiology 37: 521-551.

Clotuche, E. \& Schaeken, P., 1991: Evolution récente du statut du Grand cormoran (Phalacrocorax carbo) en Meuse liégeoise. - AVES 28: 223-225.

Cragg-Hine, D. \& Jones, J. W., 1969: Growth of dace Leuciscus leusciscus (L), roach Rutilus rutilus (L) and chub Squalius cephalus (L) in Willow Brook, Northamptonshire. - Journal of Fish Biology 1: 59-82.

Dahm, E., Hartmann, J., Loeffler, H. \& Voelzke, V., 1992: Review of the European Inland Fisheries Advisory Commission (EIFAC) experiments on stock assessment in lakes. - Journal of Applied Ichthyology 8: 1-9.

Daufresne, M., Roger, M.C., Capra, H. \& Lamouroux, N., 2003: Long-term changes within the invertebrate and fish communities of the Upper Rhône River: effects of climatic factors. - Global Change Biology 10: 124-140.

Descy, J.-P., 1987: Phytoplankton composition and dynamics in the River Meuse (Belgium). - Archiv für Hydrobiologie Supplement 78: 225-245.

Descy, J.-P., Kestemont, P., Everbecq, E., Verniers, G., Usseglio-Poletera, P., Gérard, P., et al., 2009: The Meuse River Basin. - In: Tockner, K., Uehlinger, U. \& Robinson, C. T. (eds): Rivers of Europe. - Elsevier, London, pp. 154-165.

Didier, J. \& Micha, J.-C., 1996: Dynamique de population du gardon en Meuse et stratégie de gestion. - Presses Universitaires de Namur, Namur, pp. 1-106.

Donkers, P., Patil, J. G., Wisniewski, C. \& Diggle, J. E., 2011: Validation of mark-recapture population estimates for invasive common carp, Cyprinus carpio, in Lake Crescent, Tasmania. - Journal of Applied Ecology 28: 7-14.

Eie, J. A. \& Borgstørm, R., 1981: Distribution and food of roach (Rutilus rutilus L.) and perch (Perca fluviatilis L.) in the eutrophic Lake Årungen, Norway. - Verhandlungen der Internationalen Vereinigung der Limnologie 21: 1257-1263.

Evrard, G. \& Micha, J.-C., 2003: Dynamique de population du gardon en Meuse namuroise après arrêt des repeuplements. Presses Universitaires de Namur, Namur, p. 1-34.

Evrard, G. \& Tarbe, A.-L., 2002: Etude du régime et de la sélectivité alimentaire du Grand Cormoran (Phalacrocorax carbo sinensis) hivernant en Haute-Meuse belge. - Aves 39: 159-178.

Evrard, G., Dermien, F., De Gottal, P., Monmart, A., Pourignaux, F., Vanmeerbeeck, P. \& Paquet, J.-Y., 2005: Estimation de la pression de pêche du Grand Cormoran (Phalacrocorax carbo) en Meuse belge par le suivi de la dispersion matinale des individus. - Aves 42: 121-133.

Foote, K. G. \& Stefansson, G., 1993: Definition of the problem of estimating fish abundance over an area from acoustic linetransect measurement of density. - ICES Journal of Marine Science 50: $369-381$.

Gatz, A. J. \& Loar, J. M., 1988: Petersen and removal population size estimates: combining methods to adjust and interpret results when assumptions are violated. - Environmental Biology of Fishes 21: 293-407. 
Giannetto, D., Carosi, A., Ghetti, L., Viali, P. \& Lorenzoni, M., 2014: Size selectivity of gill-nets and growth of roach Rutilus rutilus (Linnaeus, 1758: Piediluco lake (Italy). - Knowledge and Management of Aquatic Ecosystems 413: 1-13.

Goffaux, D., Grenouillet, G. \& Kestemont, P., 2005: Electrofishing versus gillnet sampling for the assessment of fish assemblages in large rivers. - Archiv für Hydrobiologie 162: 73-90.

Goldspink, C. R., 1979: The population density, growth rate and reproduction of roach Rutilus rutilus (L.) in Tjeukemeer, The Netherlands. - Journal of Fish Biology 15: 473-498.

Gresswell, R. E., Liss, W. J., Lomnicky, G. A., Deimling, E. K., Hoffman, R. L. \& Tyler, T., 1997: Using mark-recapture methods to estimate fish abundance in small mountain lakes. - Northwest Science 71: 39-44.

Griffiths, D. \& Harrod, C., 2007: Natural mortality, growth parameters, and environmental temperature in fishes revisited. - Canadian Journal of Fisheries and Aquatic Sciences 64: 249-255.

Guthruf, J., 2002: Die Biologie des Routages im Luganersee (Kanton TI). - Buwal, Mitteilungen zur Fischerei 74: 90.

Hamley, J. M., 1975: Review of gillnet selectivity. - Journal of the Fisheries Research Board of Canada 32: 1943-1969.

Holm, S., 1979: A simple sequentially rejective multiple test procedure. - Scandinavian Journal of Statistics 6: 65-70.

Huet, M., 1949: Aperçu des relations de la pente et des populations piscicoles des eaux courantes. - Schweizerische Zeitschrift für Hydrobiologie 11: 332-351.

Jackson, C. H. N., 1939: The analysis of an animal population. - Journal of Animal Ecology 8: 238-246.

Karatayev, A. Y., Burlakova, L. E. \& Padilla, D. K., 1997: The effects of Dreissena polymorpha (Pallas) invasion on aquatic communities in Eastern Europe. - Journal of Shellfish Research 16: 187-203.

Kelso, J. R. M. \& Shuter, B. J., 1989: Validity of the removal method for fish population estimation in a small lake. - North American Journal of Fisheries Management 9: 471-476.

Kimmerer, W. J., Gartside, E. \& Orsi, J. J., 1994: Predation by an introduced clam as the likely cause of substantial declines in zooplankton of the San Francisco Bay. - Marine Ecology Progress Series 113: 81-93.

Kottelat, M. \& Freyhof, J., 2007: Handbook of European freshwater fishes. - Publications Kottelat, Cornol and Freyhof, Berlin, pp. 1-646.

Larinier, M., 1998: Upstream and downstream fish passage experience in France. - In: Jungwirth, M., Schmultz, S. \& Weiss, S. (eds): Fish Migration and Fish Bypasses. - Fishing News Books, Vienna, pp. 127-145.

Laurent, M. \& Lamarque, P., 1975: Utilisation de la méthode des captures successives (De LURY) pour l'évaluation des peuplements piscicoles. - Bulletin Français de Pêche et de Pisciculture 259: 66-77.

Lee, R. M., 1920: A review of the methods of age and growth determination in fishes by means of scales. - Fisheries Investigations Series II, Marine Fisheries Great Britain Ministry of Agriculture Fisheries and Food 4: 1-32.

Mallen-Cooper, M. \& Brand, D. A., 2007: Non-salmonids in a salmonid fishway: what do 50 years of data tell us about past and future fish passage? - Fisheries Management and Ecology 14: 319-332.

Mann, R. H. K., 1973: Observations on the age, growth, reproduction and food of the roach, Rutilus rutilus (L.) in two rivers in southern England. - Journal of Fish Biology 5: 707-736.
Micha, J. C. \& Borlée, M. C., 1989: Recent historical changes on the Belgian Meuse. - In: Petts, G. E. \& Möller, H. (eds): Historical Changes of Large Alluvial Rivers: Western Europe. - John Wiley \& Sons, Chichester, pp. 269-295.

Micha, J.C. \& Pilette, S., 1988: L'impact de l'homme sur l'écosystème Meuse. - In: Actes du colloque tenu à Namur (Belgique) les 3 et 4 novembre 1988, Namur, 3-4 Novembre 1988. - Presses Universitaires de Namur, Namur, pp. 1-140.

Mehner, T., Diekmann, M., Brämick, U. \& Lemcke, R., 2005: Composition of fish communities in German lakes as related to lake morphology, trophic state, shore structure and humanuse intensity. - Freshwater Biology 50: 70-85.

Moyle, P. B., Herbold, B., Stevens, D. E. \& Miller, L. W., 1992: Life history and status of delta smelt in the Sacramento-SanJoaquin Estuary, California. - Transactions of the American Fisheries Society 121: 67-77.

Murphy, B. R. \& Willis, D. W. (eds), 1996: Fisheries techniques, 2nd ed. - American Fisheries Society, Bethesda, Maryland, pp. 1-732.

Naddafi, R., Abdoli, A., Kiabi, B. H., Amiri, B. M. \& Karami, M., 2005: Age, growth and reproduction of the Caspian roach (Rutilus rutilus caspicus) in the Anzali and Gomishan wetlands, North Iran. - Journal of Applied Ecology 21: 492-497.

Okgerman, H., Muammer, O. \& Yigit, S., 2009: Biological aspects of Rutilus rutilus (roach) in Sapanca Lake (Turkey). - Journal of Animal and Veterinary Advances 8: 441-446.

Olin, M., Rask, M., Ruuhijärvi, J., Kurkilahti, M., Ala-Opas, P. \& Ylönen, O., 2002: Fish community structure in mesotrophic and eutrophic lakes of Southern Finland: the relative abundance of percids and cyprinids along a trophic gradient. - Journal of Fish Biology 60: 593-612.

Olin, M., Malinen, T. \& Ruuhijärvi, J., 2009: Gillnet catch in estimating the density and structure of fish community Comparison of gillnet and trawl samples in a eutrophic lake. - Fisheries Research 96: 88-94.

Paquet, J.-Y., 2007: Les recensements coordonnés des Grands Cormorans (Phalacrocorax carbo) hivernant en Wallonie et à Bruxelles : hiver 2006-2007. - Aves 44: 251-254.

Paquet, J.-Y., 2011: Recensements coordonnés des dortoirs de Grand Cormoran Phalacrocorax carbo en Wallonie et à Bruxelles : résultats 2010-2011. - Aves 48: 249-252.

Paquet, J.-Y., 2014: Détermination de la pression de prédation du Grand Cormoran sur le bief de Tailfer (Meuse namuroise) 2013-2014. - Unpublished report, pp. 1-10.

Pauly, D., 1980: On the interrelationships between natural mortality, growth parameters, and mean environmental temperature in 175 fish stocks. - Journal du Conseil International pour l'Exploration de la Mer 39: 175-192.

Pauly, D., 1997: Méthode pour l'évaluation des ressources halieutiques. - Cépaduès-Editions, Toulouse.

Pauly, D. \& Munro, J., 1984: Once more on the comparison of the growth in fish and invertebrates. - Fishbyte Newsletter of the Network of Tropical Fisheries Scientists 2: 21.

Peltonen, H., Ruuhijärvi, J., Malinen, T. \& Horppila, J., 1999: Estimates of roach (Rutilus rutilus (L.)) and smelt (Osmerus eperlanus (L.)) stocks with virtual population analysis, hydroacoustics and gillnet CPUE. - Fisheries Research 44: 25-36.

Petersen, C. G. J., 1896: The yearly immigration of young plaice into the Limfjord from the German Sea. - Report of the Danish Biological Station 6: 5-84.

Phillipart, J.-C., 1995: Is captive breeding an effective solution for the preservation of endemic species? - Biological Conservation 72: 281-295. 
Pigneur, L.-M., Falisse, E., Roland, K., Everbecq, E., Deliège, J.-F., Smitz, J. S., Van Doninck, K. \& Descy, J.-P., 2014: Impact of invasive Asian clams, Corbicula spp., on a large river ecosystem. - Freshwater Biology 59: 573-583.

Poff, N.L., Allan, J. D., Bain, M. B., Karr, J. R., Prestegaard, K. L., Richter, B. D., Sparks, R. E. \& Stromberg, J. C., 1997: The natural flow regime. - Bioscience 47: 769-784.

Ponton, D. \& Gerdeaux, D., 1987: La population du gardon (Rutilus rutilus (L.)) du lac Léman en 1983-85. Structure en âge, déterminisme du recrutement, analyse de la croissance. - Bulletin Français de la Pêche et de la Pisciculture 305: 43-53.

Przybylski, M., 1996: Variation in fish growth characteristics along a river course. - Hydrobiologia 325: 39-46.

Pusey, B. J., Kennard, M. J., Arthur, J. M. \& Arthington, A. H., 1998: Quantitative sampling of stream fish assemblages: single vs. multiple pass electrofishing. - Australian Journal of Ecology 23: 365-374.

Quinn, T. J. \& Deriso, R. B., 1999: Quantitative fish dynamics. - Oxford University Press, New York, pp. 1-560.

Ricker, W. E., 1975: Computation and interpretation of biological statistics of fish populations. - Bulletin of the Fisheries Research Board of Canada 191, pp. 1-401.

Rosenberger, A. E. \& Dunham, J. B., 2005: Validation of abundance estimates from mark-recapture and removal technics for rainbow trout captured by electrofishing in small streams. - North American Journal of Fisheries Management 25: 1395-1410.

Rufilson, R.A., 1991: Finfish utilization of man-initiated and adjacent natural creeks of South Creek estuary, North Carolina, using multiple gear types. - Estuaries 14: 447-467.

Schnute, J. T. \& Hilborn, R., 1993: Analysis of contradictory data sources in fish stock assessment. - Canadian Journal of Fisheries and Aquaculture Sciences 50: 1916-1923.

Sparre, P. \& Venema, S. C., 1996: Introduction à l'évaluation de stocks de poissons tropicaux, Première partie: manuel. - FAO, Document technique sur les pêches, 3036: Rév. 1, , Rome, pp. 1-401.

Submitted: 18 June 2015; accepted: 18 September 2015.
Tans, M., 2000: Utilisation de noues de la Meuse en tant que sites de reproduction et de nurserie par les poissons du fleuve. - PhD Thesis, University of Namur, Namur.

Thompson, W. L., White, G. C. \& Gowan, C., 1998: Monitoring vertebrate populations. - Academic Press, San Diego.

Vøllestad, L.A. \& L'Abée-Lund, J. H., 1987: Reproductive biology of stream-spawning roach, Rutilus rutilus. - Environmental Biology of Fishes 18: 219-227.

Volta, P. \& Jepsen, N., 2008: The recent invasion of Rutilus rutilus (L.) (Pisces: Cyprinidae) in a large South-Alpine lake: Lago Maggiore. - Journal of Limnology 67: 163-170.

Von Bertalanffy, L., 1938: A quantitative theory of organic growth. - Human Biology 10: 181-213.

Welch, B. L., 1951: On the comparison of several mean values: an alternative approach. - Biometrika 38: 330-336.

White, G. C., Anderson, D. R., Burnham, K. P. \& Otis, D. L., 1982: Capture-recapture and removal methods for sampling closed populations. - Report LA-8787-NERP, Los Alamos National Laboratory, Los Alamos.

Willemsen, J., 1980: Fishery-aspects of eutrophication. Aquatic Ecology 14: 12-21.

Williams, W. P., 1965: The population density of four species of freshwater fish, roach (Rutilus rutilus (L.)), bleak (Alburnus alburnus (L.)), dace (Leuciscus leuciscus (L.)) and perch (Perca fluviatilis (L.)) in the River Thames at Reading. Journal of Animal Ecology 34: 173-185.

Winfield, I. J., 1992: Threats to the lake fish communities of the UK arising from eutrophication and species introductions. Netherlands Journal of Zoology 42: 233-242.

Wyatt, R. J., 1988: The cause of extreme year class variation in a population of roach, Rutilus rutilus L., from a eutrophic lake in southern England. - Journal of Fish Biology 32: 409-421. 
